\title{
Perancangan Interior Kafe dengan Konsep Arsitektur Tionghoa Palembang
}

\author{
Widi Dwi Satria ${ }^{1 *}$, Antusias Nurzukhrufa ${ }^{1}$, Verza Dillano Gharata ${ }^{1}$
}

\author{
${ }^{1}$ Dosen, Program Studi Arsitektur, Jurusan Teknologi Infrastruktur dan Kewilayahan, Institut Teknologi Sumatera \\ *Penulis Korespondensi: widi.satria@ar.itera.ac.id
}

\begin{abstract}
Abstrak:
Perkembangan bisnis di dunia foods and beverages mengalami peningkatan yang cukup pesat khususnya pada bidang kafe \& restoran. Fenomena ini banyak ditemui baik di kota besar maupun di kota kecil yang mana mulai bermunculan suatu tempat makan dengan konsep yang lebih kekinian dan terkonsep dengan tujuan sasaran kepada para kaum muda. Stamps Kafe merupakan salah satu kafe baru di Kota Palembang yang bergerak di bidang kuliner dengan fokus pada masakan tradisional Palembang. Stamps Kafe juga menyediakan mini bar sebagai tempat bagi pecinta kopi untuk menikmati racikan kopi tradisional. Unsur yang akan diterapkan pada kafe ini adalah unsur Tionghoa Palembang yang dikemas dengan konsep yang lebih modern dan kekinian dengan tujuan menampilkan nuansa klasik dan modern yang dibalut oleh tema Tionghoa Palembang menjadi satu kesatuan yang seimbang. Hasil dari penelitian ini berupa gambar rancangan interior kafe secara umum, 3D desain dan video animasi suasana interior yang di desain dengan dominasi warna cerah dan penataan aksesoris sesuai pada ciri khas rumah masyarakat Tionghoa Palembang. Dengan interior kafe bertema arsitektur Tionghoa Palembang ini, diharapkan dapat memberikan nilai jual tersendiri bagi para pelaku usaha yang dimana interior kafe merupakan salah satu daya tarik yang memiliki nilai komersil tersendiri sehingga dapat memberikan keuntungan pada pemilik kafe.
\end{abstract}

Kata Kunci: Desain Interior, Kafe, Tionghoa, Palembang

\section{Latar Belakang}

Perkembangan kafe di Indonesia menunjukkan peningkatan yang cukup signifikan pada masa sekarang. Hal ini dapat dilihat dari banyak bermunculannya kafe dengan berbagai macam tema dan konsep yang menarik di Indonesia. Kafe merupakan salah satu tempat yang digunakan untuk berkumpul dan bersantai untuk melepas rasa capek dan penat setelah melakukan rutinitas sehari-hari (Audrey et al., 2020). Kafe pada umumnya menyediakan makanan dan minuman yang dikemas dengan tampilan yang menarik dan kekinian. Perbedaan antara kafe dengan tempat makan seperti restoran yaitu kafe lebih mengutamakan kenyamanan pengunjung dan hiburan untuk pengunjung dengan konsep dan suasana ruang yang berbeda (Honggowidjaja, 2018). Pada masa sekarang ini, kafe yang beroperasi memiliki daya saing yang cukup tinggi pada sisi pelayanan maupun konsep desain ruangan. Selain menu makanan dan minuman, kafe juga dibuat dengan konsep yang menarik dengan tujuan agar pengunjung dapat menghabiskan waktu lebih lama di dalam kafe dan dapat memesan banyak menu makanan selama berada di kafe (Panjaitan, 2016).

Aktivitas yang biasa dilakukan oleh pengunjung kafe yang didominasi oleh kalangan usia produktif meliputi berbagai hal. Ada yang mengunjungi kafe untuk sekedar menikmati hidangan kuliner atau ada juga mengunjungi kafe untuk bersantai dan mengambil beberapa foto untuk dapat dibagikan di media sosial untuk dapat diketahui oleh banyak orang (Salendra, 2014). Generasi muda dan usia produktif menyukai lifestyle yang cenderung berorientasi pada nilai kebendaan dan prestise. Perilaku tersebut dapat dilihat dari kebiasaan pengunjung yang lebih memilih menghabiskan banyak waktu untuk bercengkrama sambil menikmati suasana kafe yang nyaman. Perubahan dan perkembangan desain tempat makan dan minum kopi dengan konsep yang unik dan menarik akan mempengaruhi ketertarikan pengunjung untuk datang ke kafe serta meningkatkan nilai komersil dari kafe itu sendiri (Herlyana, 2012).

Penerapan konsep arsitektur Tionghoa Palembang pada desain interior dinilai cukup sesuai dengan tujuan kafe yang akan didesain dimana kafe ini lebih memberikan pelayanan cita rasa kuliner tradisional khas Palembang dengan sentuhan cita rasa yang modern. Interior arsitektur Tionghoa Palembang memiliki nilai estetika sendiri dimana nuansa yang diciptakan sangat merepresentasikan budaya Palembang pada masa lampau. Suku Palembang dan suku Tionghoa memiliki nilai histori tersendiri dan hidup berdampingan hingga saat ini dimana adat istiadat dan budaya yang beragam tidak menjadi penghalang untuk bersatu dan menjadikan hal baru yang lebih unik dan luar biasa (Primadona, 2011). Percampuran budaya dan letak geografis membuat nilai budaya yang dimiliki semakin kaya (Asmendo \& Ishar, 2020). Dengan menciptakan suasana interior khas Tionghoa Palembang diharapkan area kafe akan memiliki suasana yang lebih berbeda, serta memiliki nilai komersial tersendiri di dalam suatu kafe dan lebih mengangkat nilai-nilai kearifan lokal pada masa lampau di masa sekarang. Berdasarkan penjabaran dari latar belakang diatas, maka penulis menyimpulkan sebuah gagasan untuk mengangkat judul penelitian "Perancangan Interior Kafe dengan Konsep Arsitektur Tionghoa Palembang”. 


\section{Metode}

Metode yang digunakan pada penelitian ini adalah metode kualitatif deskriptif dengan melakukan eksplorasi terhadap gaya arsitektur Tionghoa Palembang yang akan dijadikan konsep utama di dalam perancangan desain interior kafe.

\subsection{Metode Kualitatif Deskriptif}

Pengumpulan data dilakukan dengan melalui proses studi pustaka, survei lapangan, tipologi serta mencari data dari internet, buku, dan lain sebagainya. Studi pustaka dengan fasilitas yang dibutuhkan dalam kafe serta literatur terkait budaya Tionghoa Palembang. Survei lapangan terkait kondisi kafe dilakukan untuk memperoleh data fisik terkait lokasi perancangan interior kafe dengan melalui proses observasi dan wawancara. Studi preseden kafe dilakukan dengan melakukan proses pencarian informasi baik di internet maupun studi langsung ke proyek sejenis yang mempunyai fungsi sama dan konsep yang unik.

Penggunaan metode kualitatif deskriptif ini ditekankan terutama pada analisis gaya arsitektur Tionghoa Palembang sebagai ruh/nyawa dari konsep desain interior. Pengumpulan informasi dan data terkait gaya arsitektur Tionghoa Palembang di dapat melalui tinjauan pustaka terhadap penelitian terkait yang pernah dilakukan.

\subsection{Metode Analisis Data}

Terdapat tiga proses analisis yang dilakukan pada perancangan ini, yaitu tahap programming, analisis, konsep dan tahap desain akhir. Tahapan programming dan perumusan masalah akan diterapkan sebagai landasan dalam proses menganalisa aktivitas pengguna serta kebutuhan ruang. Selanjutnya setelah permasalahan dan juga kebutuhan dari tahap programming didapatkan, maka akan diteruskan ke dalam tahapan analisis dimana pada proses ini dilakukan perincian dari proses programming dengan data yang diperoleh sehingga akan diberikan usulan menyesuaikan dengan kebutuhan desain interior kafe. Pada tahapan konsep, akan diambil kesimpulan dari analisis yang dijadikan proses pemecahan kebutuhan masalah ruang interior. Hasil rancangan dari konsep desain yang dirincikan selanjutnya dipertegas pada desain akhir yang akan dipergunakan sebagai aplikasi untuk proyek perancangan desain.

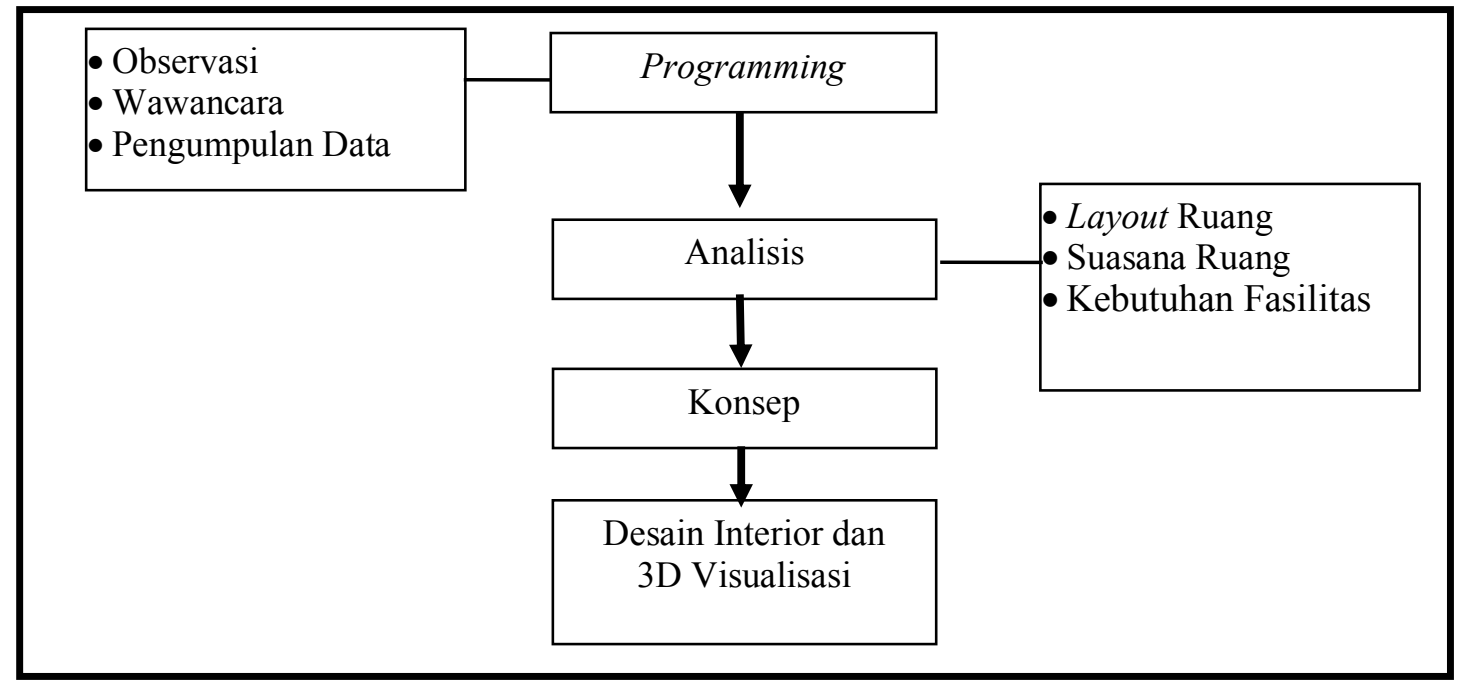

Gambar 1. Tahapan desain

Pada proses programming, dilakukan pengumpulan data-data yang berkaitan dengan kondisi eksisting kafe dan data penunjang terkait kebutuhan fasilitas di dalam kafe. Selain itu, pada tahap ini juga dikumpulkan informasi terkait dengan langgam arsitektur Tionghoa Palembang beserta motif dan nuansa ruang interiornya. Nuansa ruang, motif, dan warna ini akan dimanfaatkan pada tahap pengerjaan konsep gaya arsitektur dan suasana ruang. Penataan ruang meliputi furniture dan warna akan memberikan dampak cukup besar terhadap kenyamanan (Vandella \& Ishar, 2019). Menurut Purwanto (2016) Pengaturan furniture dan elemen interior yang unik dan inovatif akan memberikan kesan menyenangkan kepada pengunjung.

Data yang dihimpun pada tahapan programming kemudian diolah dan dianalisis. Terdapat 4 (empat) aspek yang akan dianalisis, yakni layout ruang, gaya arsitektur, dan kebutuhan fasilitas. Pada tahap konsep, dirumuskan konsep utama dari pengembangan analisis interior. Dari konsep utama ini kemudian dilengkapi dengan konsep desain dan konsep pengembangan yang lebih mendetail. Konsep pengembangan ini diantaranya adalah konsep ruang (zonasi) yang mana memiliki konsep suasana ruang yang berkaitan dengan arsitektur Tionghoa Palembang. Kesan suasana yang kuat dan berkarakter pada kafe akan menjadi alasan utama bagi pengunjung untuk selalu mengunjungi kafe (Tejo \& Wibowo, 2014).

Setelah konsep dirumuskan, tahapan selanjutnya adalah merancang interior kafe dengan memanfaatkan software 
sketchup 3D. Dari sketchup 3D dapat dihasilkan gambar 2D maupun 3D dengan bentuk yang lebih arsitektural. Hasil 3D visualisasi yang sudah dihasilkan akan merepresentasikan suasana yang sama dengan kondisi sebenarnya di lapangan dan sudah dapat dijadikan acuan dalam proses pengerjaan dan finishing interior.
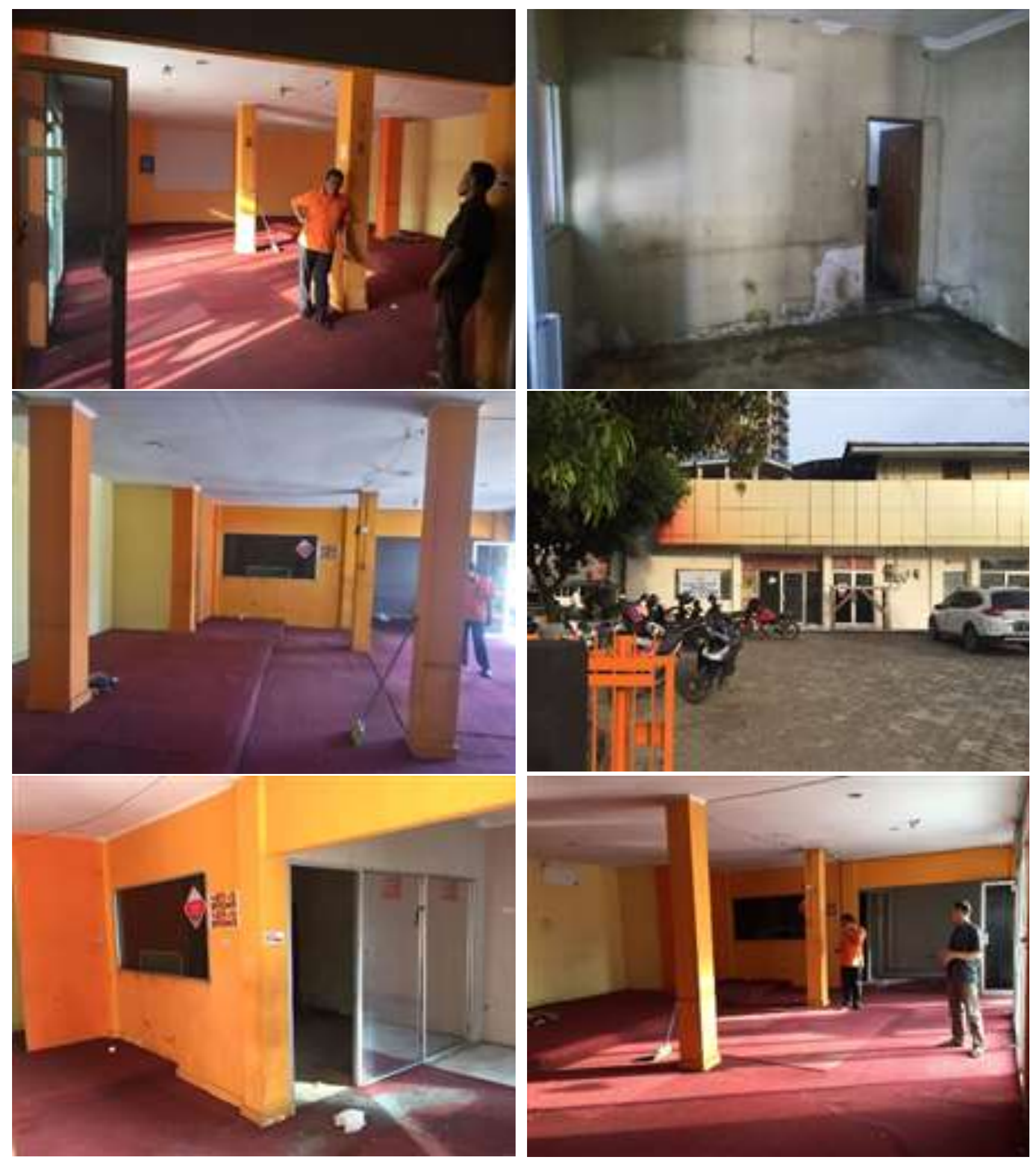

Gambar 2. Foto Eksisting Kafe

Sumber: Dokumen Pribadi

\section{Hasil dan Pembahasan}

Terdapat beberapa hasil yang didapat berdasarkan tahapan desain yang telah dilakukan. Hasil yang diperoleh dirincikan dan dibahas pada setiap tahapan untuk kemudian dilanjutkan ke dalam tahap perancangan desain interior.

\subsection{Programming}

Berdasarkan hasil programming yang telah dilakukan, didapatkan informasi bahwa lokasi kafe berada di area pusat Kota Palembang tepatnya di jalan Kapten Ahmad Rivai dengan akses yang cukup strategis bagi pengunjung. 
Kafe ini masih masuk kedalam kawasan kantor pos karena kondisi bangunan yang menyatu dengan bangunan kantor pos. Pada daerah ini juga banyak ditemui tempat makan dan tempat berbelanja.

Terkait gaya arsitektur Tionghoa Palembang, berdasarkan penelitian Aziz et al. (2020), arsitektur Tionghoa Palembang terwujud dari akulturasi budaya Cina, Belanda, dan Palembang. Akulturasi budaya pada pola ruang yang simetris dengan fasad yang tegas dikombinasikan dengan teras terbuka dengan kolom yang berjajar di depannya identik dengan arsitektur kolonial. Bahan bangunan dan sistem konstruksi sebagian menggunakan dinding tebal batu bata dan dinding kayu sebagai perpaduan arsitektur kolonial dan limas Palembang. Lalu ornamen simbolik pada pintu utama dan cat warna merah terang identik dengan arsitektur Tionghoa yang dipadukan dengan struktur pintu bukaan dua arah khas arsitektur Tionghoa Palembang. Ornamen pada rumah tradisional memiliki makna khusus, hal ini sejalan dengan temuan penelitian setiawadi \& murwadi (2019), Adiatmono (2013), dan Zamad \& Alfiah (2017) yang menyebutkan bahwa ornamen pada rumah tradisional memiliki makna yang mendalam dan menjadi kekayaan budaya tersendiri.Terkait ruang yang dibutuhkan meliputi zona publik dimana didalamnya terdapat area makan pengunjung baik indoor dan semi outdoor, live music, dan mini bar. Selanjutnya ada zona servis meliputi area toilet dan area cuci tangan, damn zona pengelola meliputi area masak, loker karyawan, dan gudang bahan. Dari data yang didapat, akan diolah interior yang dapat memenuhi segala kebutuhan ruang di dalam kafe dengan ukuran yang terbatas. Penataan ruang yang baik dan terencana akan menentukan keberhasilan dan hasil yang maksimal (Agustin et al., 2021).

\subsection{Analisis}

Berdasarkan aspek layout ruang, interior kafe yang dirancang memiliki layout yang menarik dikarenakan kondisi ruangan masih rapi dan bersih dengan cat yang masih bagus. Sehingga memudahkan dalam memetakan perletakan ruang dan mengatur suasana ruang sebaik mungkin agar terkesan memasuki rumah masa lampau. Pada area tengah ruang terdapat tiang kolom yang dapat dimanfaatkan untuk perletakkan aksesoris pendukung bagi kafe agar ruangan lebih berwarna.

Dari aspek suasana ruang, suasana interior rumah tradisional Tionghoa Palembang sangat cocok untuk diterapkan di dalam perancangan desain interior ini dikarenakan memiliki kesamaan tujuan antara menu masakan dan suasana kafe yang akan dirancang dengan mengangkat suasana klasik dari arsitektur Tionghoa Palembang yang dikemas dalam suasana kekinian tanpa mengurangi suasana aslinya.

Dari aspek kebutuhan fasilitas, kafe yang menyediakan menu masakan tradisional dan mini bar untuk menu minuman maka area mini bar akan diletakkan di area dalam dimana bisa dilihat dan langsung dipesan oleh pengunjung serta juga dapat menjadi daya tarik tersendiri. Fasilitas live music diletakkan pada area semi outdoor, kondisi udara alami agar lebih memberikan kesan santai bagi pengunjung dan juga live music dapat disaksikan oleh orang umum di sekitar kafe. Area masak berdampingan dengan gudang bahan agar memudahkan proses operasional. Kasir diletakkan dekat pintu keluar untuk memudahkan proses transaksi agar pengunjung setelah bayar bisa langsung keluar.

\subsection{Konsep}

Konsep utama dari desain interior kafe ini adalah nuansa arsitektur Tionghoa Palembang. Konsep ini merupakan gambaran yang juga diinginkan oleh pemilik kafe. Hal ini kemudian akan mempengaruhi pada pengolahan dinding ruangan dan pengaturan peletakan fasilitas kafe dan aksesoris. Konsep desain juga akan banyak berkaitan dengan pengolahan warna dan pajangan dinding yang lebih merepresentasikan nuansa rumah Tionghoa Palembang. Untuk pola desainnya, akan mengambil inspirasi dari penataan interior rumah tradisional Tionghoa Palembang dengan dikombinasi motif songket Palembang terkait warna dan pola motifnya sebagai ornamentasi pada dinding (Gambar 3). Dinding interior akan dibuat menjadi 3 bagian, dimana bagian bawah diberi warna merah untuk mempertegas ciri khas warna budaya Tionghoa. Pada bagian list dinding dengan tinggi 1-meter akan dibuatkan motif yang dimodifikasi dari bentukan yang ada pada kain songket Palembang. Pada bagian atas akan diberi warna krim untuk memberi kesan klasik yang elegan. Pada bagian kaca kafe akan dibuatkan rangka menyerupai kaca klasik khas rumah tradisional masyarakat Tionghoa. Keseluruhan konsep akan dikemas menjadi satu kesatuan yang unik dan menarik dengan ditambah unsur yang lebih kekinian. 

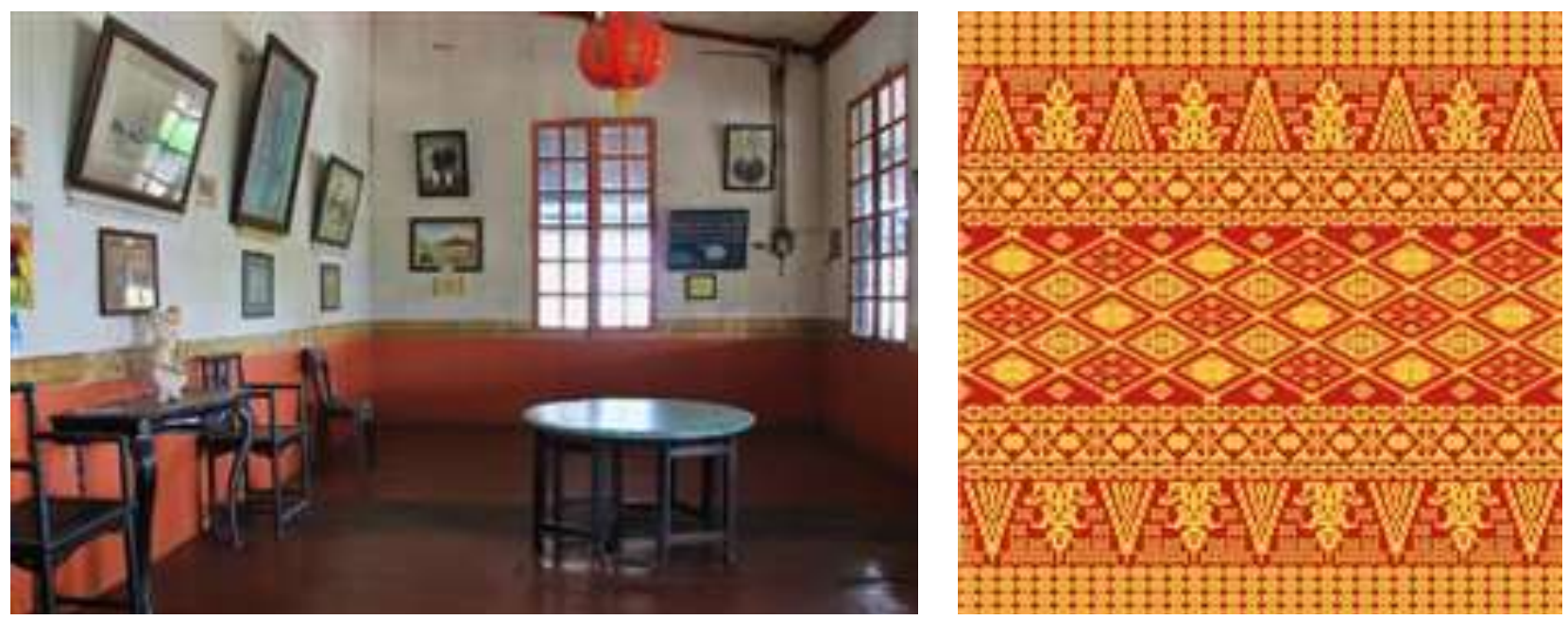

Gambar 3. Interior rumah kampung kapitan (kiri) dan Motif songket Palembang (kanan)

Sumber: indonesiakaya.com (kiri) dan afri.my.id (kanan)

Stamps Kafe akan menggunakan tiga area utama yaitu: Public area berada di luar dan didalam ruangan yang menjadi bagian utama dalam suatu ruangan. Area publik pada Stamps Kafe ini terdapat di ruang indoor dan outdoor. Pada area dalam disandingkan dengan perletakan mini bar, sedangkan pada area semi outdoor disandingkan dengan panggung music secara langsung. Private area pada stamps kafe bersifat tertutup atau sedikit ke dalam. Private area pada kafe ini yaitu pada area ruang kasir, area bar, area dapur yang hanya dapat dimasuki oleh pemilik usaha dan karyawan. Service area pada stamps afe terdapat pada area parkir dan kamar mandi.

Gaya yang akan diterapkan pada stamps kafe ini memiliki gaya desain ruangan secara garis besar mengambil gaya arsitektur Tionghoa Palembang. Akulturasi antara dua budaya yang berbeda menjadi satu kesatuan. Penggunaan warna pada Stamps Kafe banyak menggunakan warna yang ramai (colourfull). Warna yang digunakan adalah dominan merah yang mana warna merah menunjukkan ciri khas warna yang biasa ditemui pada rumah maupun kebudayaan Tionghoa. Bahkan di Kota Palembang terdapat jembatan Ampera yang berwarna merah, hal ini menunjukkan bahwa warna merah sudah menjadi ciri khas yang sudah melekat pada Kota Palembang. Tidak hanya warna merah, warna-warna pendukung seperti cream, corak kayu, hitam, dan oranye juga digunakan di beberapa bagian pada Stamps Kafe. Untuk memunculkan kesan rumah tradisional, penggunaan warna warna alam seperti coklat dan warna tanah juga ikut disertakan. Hal itu pun berlaku untuk desain interior modern karena nuansa klasik memiliki estetika tersendiri. Selain itu, tambahan warna oranye sebagai aksen juga menjadi unsur penting guna menciptakan kesan kuat dan kokoh serta memperkuat tampilan objek di dalam ruangan dimana warna oranye merupakan warna yang biasa ditemui pada warna songket Palembang.

Warna interior yang digunakan adalah warna dasar dari konsep arsitektur Tionghoa Palembang yang lebih dominan menggunakan warna cerah dan berkesan kokoh dan warna yang lebih alami mendekati wujud bahan yang dipergunakan seperti warna hitam yang diterapkan pada meja dan aksesoris pendukung pada kafe untuk memberikan kesan yang kuat antara tradisional dan modern. Warna merah sendiri diterapkan pada bagian dinding dan tiang kolom dengan finishing cat agar memunculkan kesan cerah dan meriah agar nuansa Tionghoa Palembang nya lebih terlihat. warna krim untuk finishing pada bagian dinding untuk memberikan perpaduan warna yang bersih dan nyaman. Warna coklat diterapkan pada beberapa bagian furniture dan railing pembatas pada area semi outdoor yang menghasilkan kesan natural serta juga segar. Untuk material sendiri menggunakan bahan glassfiber reinforced concrete (GRC) untuk bagian atap pada bangunan kafe. Sedangkan tekstur kayu untuk bagian meja dan kursi serta railing pembatas untuk ambalan meja kasir dan bar menggunakan material keramik berwarna hitam untuk memberikan kesan kokoh. Untuk meja dapur menggunakan gabungan meja beton dengan ambalan keramik putih serta meja alumunium untuk memberikan kesan bersih. 


\subsection{Desain Interior dan 3D Visualisasi}

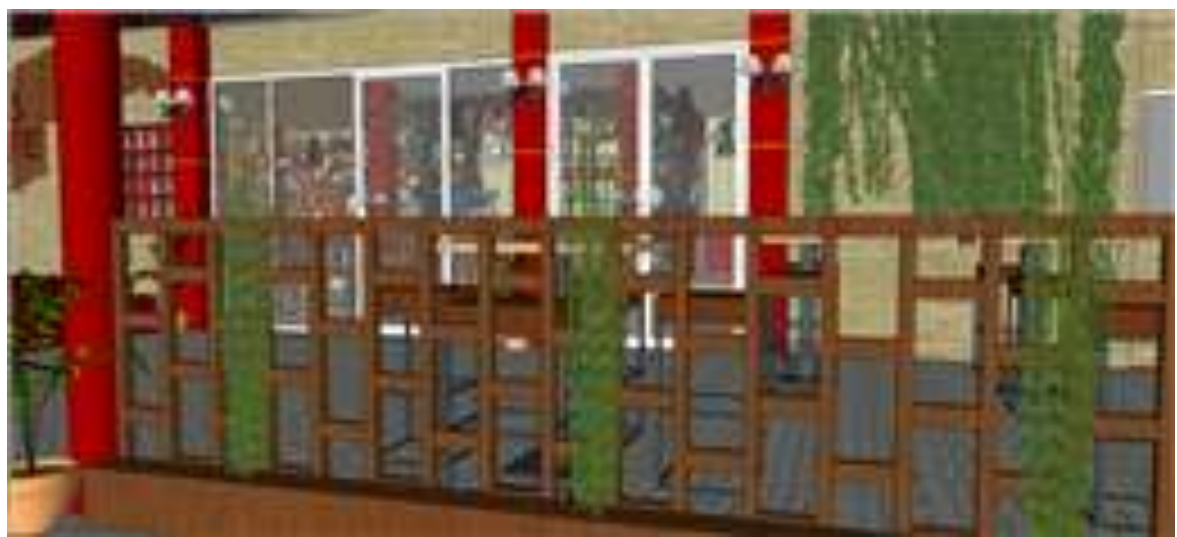

Gambar 4. Desain railing area semi outdoor

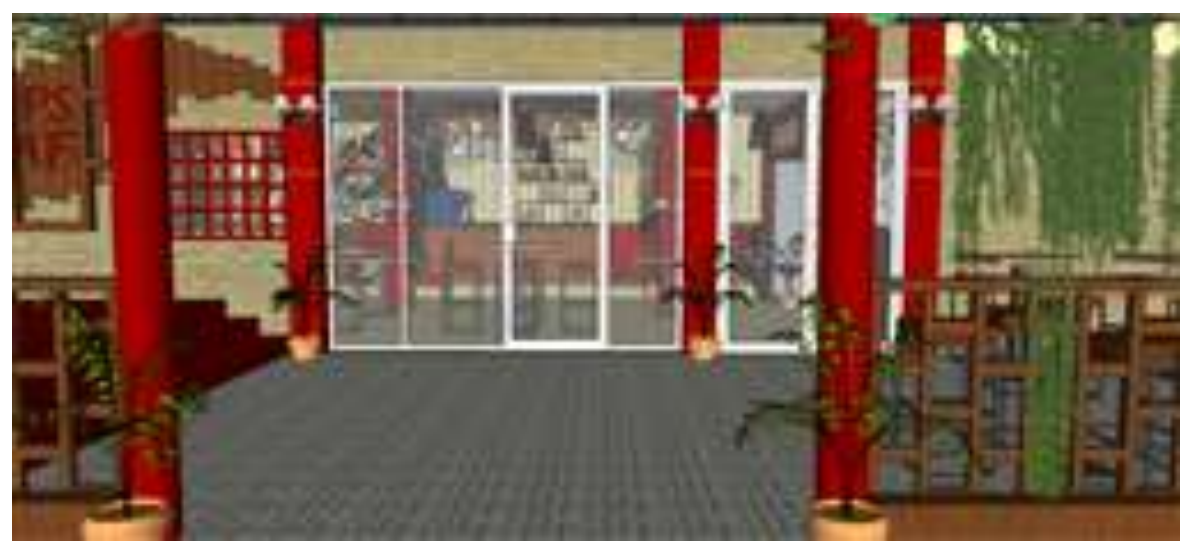

Gambar 5. Entrance kafe

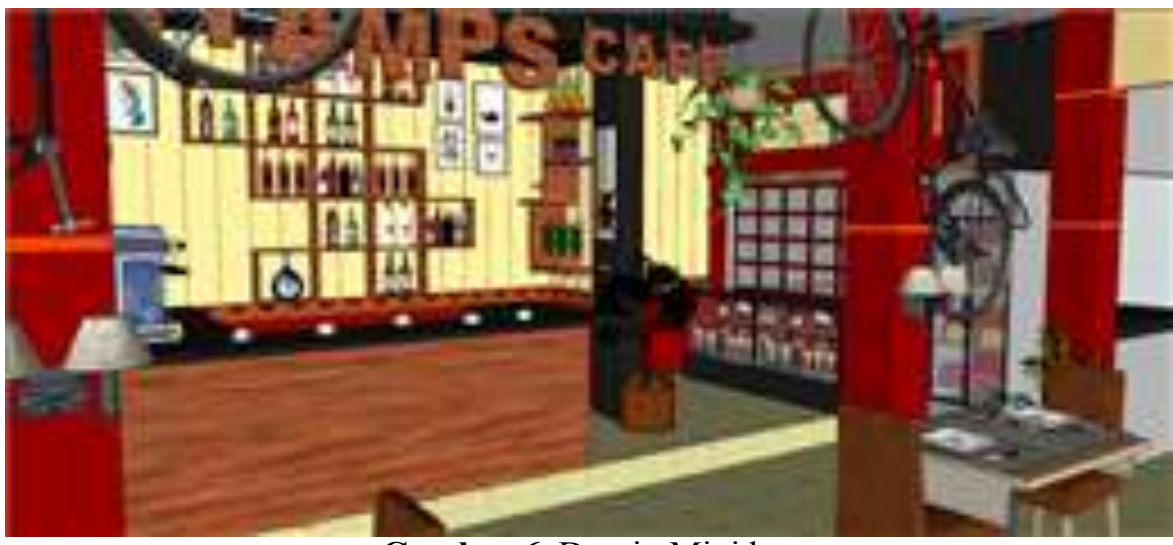

Gambar 6. Desain Mini bar

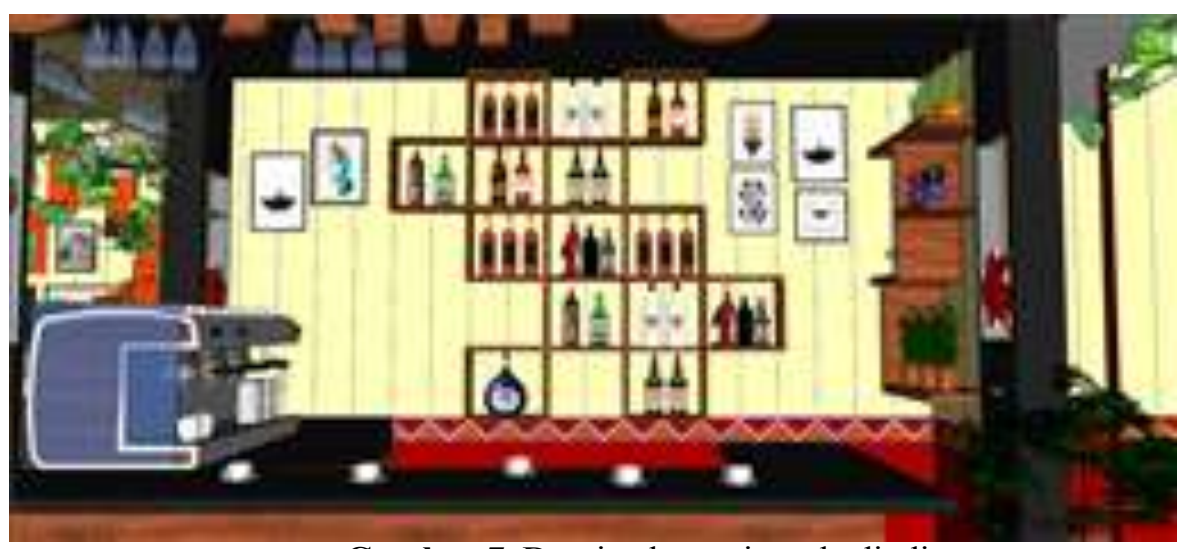

Gambar 7. Desain aksesoris pada dinding 


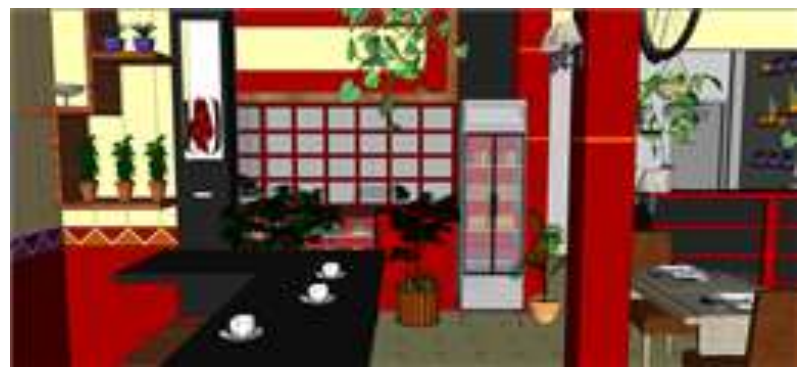

Gambar 8. View area dapur

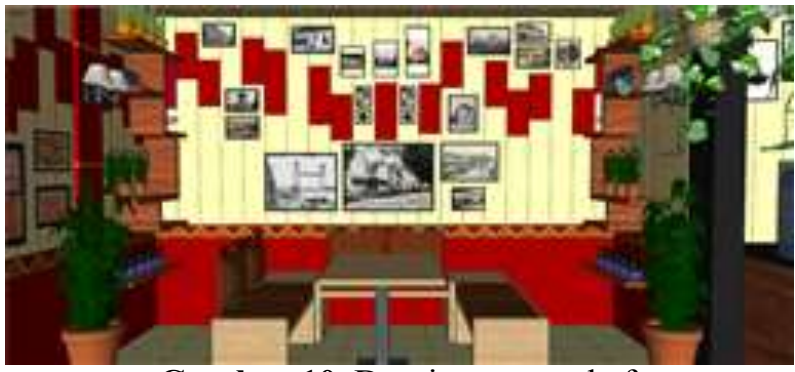

Gambar 10. Desain suasana kafe

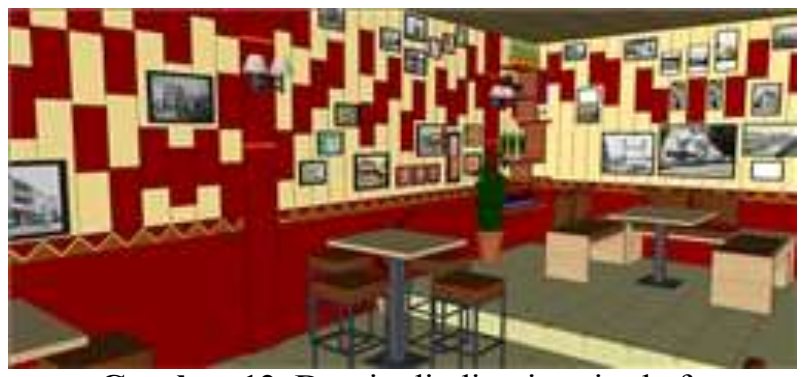

Gambar 12. Desain dinding interior kafe

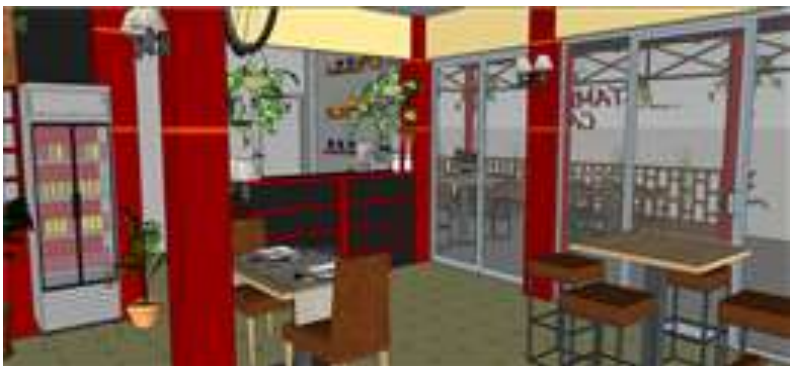

Gambar 9. View ke area kasir

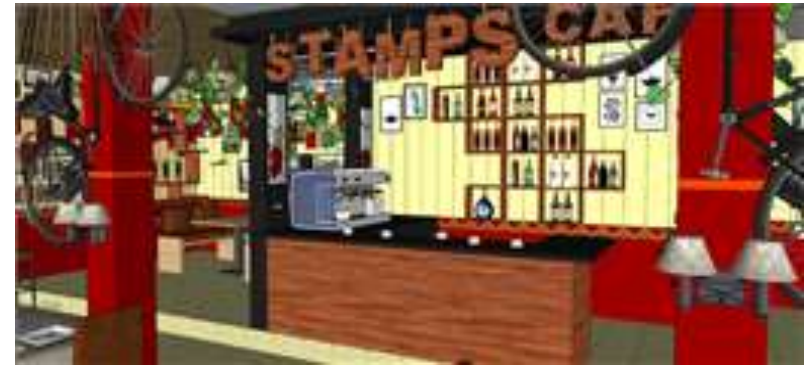

Gambar 11. Aksesoris pada mini bar

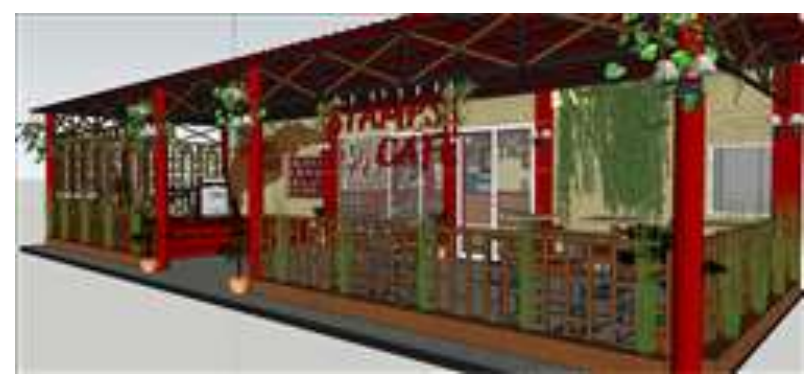

Gambar 13. Tampak depan suasana kafe

Sumber : Dokumen Pribadi

Desain pada gambar 4 dan 5 merupakan suasana entrance dari kafe yang mana entrance dibuat dengan memadukan pola warna komponen arsitektur berupa railing pembatas untuk area semi outdoor. Railing yang dibuat terinspirasi dari rumah tradisional masyarakat Tionghoa Palembang di Kampung Kapitan yang menggunakan pembatas railing karena hal itu dimaksudkan sebagai pengaman sekaligus penambah estetika.

Pada gambar 6 dan 7 merupakan visualisasi dari area mini bar yang mana didominasi dengan warna coklat perpaduan hitam untuk memberikan kesan klasik dan tegas serta dengan background dinding yang dominan warna merah dan cream dengan lis dinding dengan mengambil motif dari songket. Pada bagian dinding juga dibuatkan rak untuk memajang aksesoris khusus mini bar. Pada bagian kaca yang mengarah ke area dapur dibuatkan frame yang rapat mengikuti bentuk frame kaca rumah tradisional Tionghoa Palembang untuk mempertegas suasana ruang yang klasik khas rumah tradisional masyarakat Tionghoa Palembang (gambar 8). Pada gambar 9 terlihat tiang kolom yang berwarna merah dengan list warna oranye untuk menciptakan aksen mengikuti perpaduan warna pada kain songket Palembang. Terlihat juga meja kasir yang berwarna hitam dengan list merah untuk menciptakan kesan klasik yang tegas.

Pada gambar 10 merupakan spot khusus untuk foro-foto bagi pengunjung karena kafe selain sebagai tempat makan juga bisa sebagai tempat untuk mengabadikan momen berharga. Area ini dibuat lebih khusus dan memiliki meja dan kursi berbeda serta pada bagian dinding dihiasi dengan pajangan foto-foto masa lampau kota Palembang. Pada area ini juga dilengkapi aksesoris tambahan berupa rak untuk pajangan. Terdapat nama stamps kafe pada area mini bar untuk mempertegas nama kafe yang mana papan nama dibuat dari neon box yang warna nya disesuaikan dengan warna kayu untuk memberi kesan klasik (gambar 11).

Pada gambar 12 menunjukkan area pada dinding interior kafe secara keseluruhan dimana pada area dinding didominasi warna merah, krim, dan oranye serta ditambahkan motif songket pada list dinding nya. Pada area dinding juga diberikan bentukan racana dinding dengan membentuk irama tertentu. Hal ini bertujuan untuk memberikan banyak ornamen pada dinding untuk memberikan kesan ramai dan berwarna sesuai dengan budaya Tionghoa yang syarat akan sesuatu yang ramai apabila sudah tiba hari perayaan tertentu. Gambar 13 merupakan tampilan semi outdoor kafe dimana pada tampilan entrance didominasi dengan warna merah dengan penggunaan tiang pipa besi dengan warna merah sebagai penguat struktur dan terkesan lebih kokoh. Ada area ini diberi pagar pembatas dengan pola yang sudah di modifikasi agar terlihat lebih kekinian. 


\section{Kesimpulan}

Konsep arsitektur Tionghoa Palembang memiliki ciri khas dan keunikan tersendiri yang memiliki nilai bersejarah. Penerapan Konsep arsitektur Tionghoa Palembang dalam perencanaan dan perancangan interior kafe merupakan suatu wujud perhatian dan apresiasi terhadap keunikan arsitektur lokal Palembang yang dikemas menjadi suatu interior kafe yang memiliki nilai komersil tinggi. Desain interior Stamps Kafe dapat menjadi pelopor kafe yang mengedepankan kearifan lokal di era modern saat ini.

\section{Ucapan TerimaKasih}

Ucapan terima kasih saya sampaikan kepada pemilik Stamps Kafe \& Resto atas kepercayaannya kepada kami untuk dapat mendesain interior kafe dengan konsep arsitektur Tionghoa Palembang dan juga telah diberikan izin dalam memudahkan selama pengumpulan data serta kelancaran komunikasi dalam penyampaian hasil desain. Semoga hubungan baik yang telah terjalin dapat bertahan selamanya.

\section{DaftarPustaka}

Adiatmono, F. (2013). Identitas Ornamen Rumah Tradisional. Jurnal Seni Rupa ATRAT, 1(2), 30-49.

Agustin, D., M, M. H., Nabila, R. T., \& Z, A. I. (2021). Tipologi Ruang Dalam Rumah Lamin Berdasarkan Sistem Adat Pada Masyarakat Suku Dayak. Jurnal Arsitektur, 11(1), 33.

Asmendo, F., \& Ishar, S. I. (2020). Studi Komparasi Tipologi Arsitektur Rumah Limas di Provinsi Lampung dengan Rumah Limas di Sumatera Selatan. Jurnal Arsitektur, 10(2), 95.

Audrey, J., Wibowo, M., Studi, P., Interior, D., Petra, U. K., \& Siwalankerto, J. (2020). Perancangan Interior Café Thematic di Surabaya. Jurnal Intra, 8(1), 24-29.

Aziz, A. M. A., Rukayah, R. S., \& Wijayanti, W. (2020). Arsitektur Rumah Tradisional Di Kawasan Kampung Kapitan Palembang. Jurnal Arsitektur ARCADE, 4(3), 199.

Herlyana, E. (2012). Fenomena Coffee Shop Sebagai Gejala Gaya Hidup Baru Kaum Muda. ThaqÃfiyyÃT, 13(1), 188204.

Honggowidjaja, M. P. \& S. P. (2018). Perancangan Interior Restaurant China - Dayak Di Kalimantan Barat. Jurnal Intra, 6(2), 193-199.

Panjaitan, S. W. (2016). Analisa Konsep Desain Interior Terhadap Segmentasi pada Pengunjung Sebuah Kafe. Jurnal Proporsi, 2(1), 23-34.

Primadona, G. I. (2011). Perancangan Kawasan Terpadu Wisata Alam dan Budaya. Jurnal Arsitektur, 2(1), 43-58.

Purwanto G.I. (2016). Perancangan Interior Coffee House di Surabaya. Jurnal Intra, 4(2), 651-661.

Salendra. (2014). Coffee Shop As a Media for Self-Actualization Today's Youth. The Messenger, VI(2), 49-58.

Setiawati, E., \& Murwadi, H. (2019). Studi Komparatif Ornamen Rumah Adat Lampung Studi Kasus: Rumah Adat Lampung Saibatin Lampung Barat. Jurnal Arsitektur, 9(1), 33.

Tejo, L. M., \& Wibowo, M. (2014). Studi Gaya Vintage pada Interior Cafe Di Surabaya . Jurnal Intra, 2(2), 107-117.

Vandella, R., \& Ishar, S. I. (2019). Kajian Penempatan Furniture dan Pemakaian Warna Kamar Hotel (Studi Kasus: Hotel Sheraton \& Hotel Horison di Bandarlampung). Jurnal Arsitektur, 9(1), 23.

Zamad, N., \& Alfiah, A. (2017). Identitas Arsitektur Mandar Pada Bangunan Tradisional Di Kabupaten Majene. Nature : National Academic Journal of Architecture, 4(1), 1-10. 